\title{
N-Acetylglucosaminyl 1-Phosphate Transferase: An Excellent Target for Developing New Generation Breast Cancer Therapeutic
}

\author{
Aditi Banerjee $^{1,{ }^{*}}$, Juan A. Martinez ${ }^{1}$, Maria O. Longas ${ }^{3}$, Zhenbo Zhang $^{1}$, Jesus Santiago ${ }^{1}$, \\ Krishna Baksi ${ }^{4}$, and Dipak K. Banerjee ${ }^{1,2}$ \\ ${ }^{1}$ Department of Biochemistry, School of Medicine, University of Puerto Rico, Medical Sciences \\ Campus, San Juan, PR 00936-5067, USA \\ ${ }^{2}$ Institute of Functional Nanomaterials, University of Puerto Rico-Rio Piedras, San Juan, \\ PR00931-1907, USA \\ ${ }^{3}$ Department of Chemistry and Physics, Purdue University Calumet Hammond, IN 46323-2094, \\ USA \\ ${ }^{4}$ Department of Anatomy and Cell Biology, School of Medicine, Universidad Central del Caribe, \\ Bayamon, PR 00960-3001, USA
}

\begin{abstract}
Studies from our laboratory have explained that breast tumor progression can be attenuated by targeting the N-linked glycoproteins of the tumor microvasculature and that of tumor cells alike with a protein $\mathrm{N}$-glycosylation inhibitor, tunicamycin. Absence of $\mathrm{N}$-glycosylation leads to an accumulation of un- or mis-folded proteins in the ER and the cell develops "ER stress". The result is cell cycle arrest, and induction of apoptosis mediated by unfolded protein response (upr) signaling. Tunicamycin inhibited in vitro and in vivo (Matrigel ${ }^{\mathrm{TM}}$ implants in athymic nude mice) angiogenesis in a dose dependent manner. The action is irreversible and survived under tumor microenvironment, i.e., in the presence of FGF- 2 or VEGF or higher serum concentration. Importantly, tunicamycin prevented the progression of double negative $\left(\mathrm{ER}^{-} / \mathrm{PR}^{-} / \mathrm{Her} 2^{+}\right)$and triple negative (ER $/ \mathrm{PR}^{-} / \mathrm{Her} 2^{-}$) breast tumors by $\sim 55 \%$ - $65 \%$ in three weeks in athymic nude mice $[\mathrm{Balb} / \mathrm{c}(n u / n u)]$. Analyses of paraffin sections exhibited "ER stress" in both microvasculature and in tumor tissue.
\end{abstract}

\section{Introduction}

Each year, breast cancer is diagnosed in over one million women worldwide, with a survival rate of approximately 400,000 women (1). The American Cancer Society estimates the following for breast cancer in the United States for 2013: 232,340 new cases of invasive

Send all correspondence to: Dipak K. Banerjee, Ph.D. Department of Biochemistry, School of Medicine, University of Puerto Rico, Medical Sciences Campus, San Juan, PR 00936-5067. USA, Telephone: (787) 281-0155; Fax: (787) 274-8724,

dipak.banerjee@upr.edu.

*Present Address: Department of Microbiology and Immunology, University of Maryland School of Medicine and Institute of Marine and Environmental Technology, Baltimore, Maryland 21202, USA. 
breast cancer, 64,640 new cases of carcinoma in situ (CIS; non-invasive), and nearly 39,620 deaths. The disease is more common among women in upper socioeconomic classes, among women who never have been married and among women leaving in rural areas. Lower-thanaverage rates of breast cancer have been recorded for Mexican-Americans, Japanese and Filipino women in Hawaii, American Indians, Seventh-Day Adventists, and Mormons, while Jewish women have a higher-than-average risk. Nuns have a higher risk for breast cancer, presumably because of their usual nulliparous status (2).

\section{Triple Negative Breast Cancer}

The triple negative breast cancer (TNBC) accounts for $15 \%$ of all breast cancers and has a disproportionate share of mortality. In TNBC, tumors do not express estrogen receptors, progesterone receptors or Her2 (3). The patients are younger (4), and the disease is more common in pre-menopausal African-American women (5). Histology includes a high grade, a high proliferation rate, and necrosis (6,7). TNBC tends to metastasize hematogenously rather than via the lymphatics, and thus shows less axillary lymph node metastasis than nonTNBC (8). Patients with TNBC unfortunately have a higher risk of recurrence and death than those with non-triple negative tumors. Recurrence risk increases rapidly in the first 2 years, with a peak at $2-3$ years, then declines over the next 5 years (9). Majority of deaths occurs in the first 5 years (10).

Both endogenous and exogenous factors contribute to the development and progression of breast cancer. These include reproductive factors, endogenous hormones, exogenous hormones [oral contraceptives, depot-metroxyprogesterone acetate/DMPA, estrogenreplacement therapy, diethyl-stilbestrol/DES], body build, diet, alcohol consumption, lifestyle/medications/electric power use, benign breast conditions, multiple primary neoplasms, familial aggregation and heredity, estrogen receptors, and radiation (11). This is complicated further with the metastatic load due to epithelial-mesechymal transition (EMT; 12).

The disease was recognized by the Egyptians as early as $1600 \mathrm{BC}$. But, it has become a major public health problem over the last 50 years, affecting as many as one in eight women during their life time $(13,14)$. Furthermore, in many regions of the world breast cancer is the most frequently occurring malignant disease in women (15). When the deaths are aggregated by age, cancer has surpassed heart disease as the leading cause of death for those younger than age 85 since 1999. Delay-adjusted cancer incidence rates stabilized in men from 1995 through 2002, but continued to increase by 0.3\% per year from 1987 through 2002 in women (1). African-American men and women have $40 \%$ and $18 \%$ higher death rates from all cancers combined than White men and women, respectively. Furthermore, minority populations are more likely to be diagnosed with advanced stage disease than Whites. At present, breast cancer incidence rates are higher in White women than in African-Americans over age 45; the rates are similar in the 40-44 years age group, and higher in AfricanAmerican younger than age $40(16,17)$. In the United States, the incidence rate for breast cancer has increased steadily by about $1-2 \%$ per year since $1960(2,15,18,19)$. The prognosis of breast cancer depends upon the stage at diagnosis: 5-year survival rate is $100 \%$ 
for Stage $0,98 \%$ for Stage I, $88 \%$ for Stage II, $56 \%$ for Stage IIIA, $49 \%$ for Stage IIIB and $16 \%$ for Stage IV.

\section{Breast cancer therapy}

The disease is preventable if detected early and treated with appropriate therapy. Although several therapeutic options exist, the treatment of breast cancer is typically expensive and accompanied by a host of adverse side effects that are detrimental to patient's quality of life. In many cases, treatments are effective in only a small percentage of the total patient population. As a consequence, there is a poor patient outcomes, an economic burden on the healthcare system, added costs of the physician's time, wasted drugs, and increased hospitalization. In malignant breast tissue, the intratumoral endothelial cell proliferation rate is 45 times higher than that of the surrounding benign breast. Therefore, therapies have been designed to interrupt the targets of this process (20). These targets are categorized as: endothelial toxins, growth factor antagonists, protease inhibitors, and endogenous antiangiogenics (21-25). Since, the TNBCs are poorly differentiated, most of them falls into the basal subgroup of breast cancers. Because of the absence of specific treatment guidelines, TNBC patients are managed with standard treatment which leaves them with a high rate of local and systemic relapse.

\section{Breast tumor growth is angiogenesis dependent}

The hallmark of cancer follows the core principles of sustainability to proliferative signaling, ability to evade growth suppressors, ability to resistance cell death, ability to enable replicative immortality, angiogenesis induction, and activating invasion and metastasis. Neovascularization, i.e., angiogenesis is a "key" $(26,27)$ to breast cancer progression and occurs from pre-existing vasculature in stages that orchestrate a network of cooperative interactions. These include endothelial cell migration, capillary budding, establishment of capillary loops, and neovascular remodeling. A "angiogenesis switch" thus initiates the formation of new capillary tubes from host vessels (28). Factors helping the "angiogenic switch" may include, but are not limited to, the tumor microenvironment; mutation in oncogenes or tumor-suppressor genes; pro-angiogenic molecules like VEGF, FGF-2, EGF, PDGF, PIGF and MMPs; and anti-angiogenic factors (thrombospondin, angiostatin, tumstatin, and endostatin $(26,27)$.

\section{Angiogenesis depends on asparagine-linked glycoproteins}

Asparagine-linked ( $\mathrm{N}$-linked) glycoproteins have been found to play an important role in capillary endothelial cell proliferation and differentiation (29-36). It has also been suggested that inhibition of hybrid and complex-type $\mathrm{N}$-glycans synthesis inhibits the formation of capillary tubes. In contrast, inhibition of only complex-type N-glycans, but not hybrid-type $\mathrm{N}$-glycans, does not inhibit the tube formation. This suggestion supports that (a) the synthesis of at least hybrid-type glycans is required for capillary tube formation in vitro, and (b) that an increase in monosialylated, fucosylated N-linked glycans occurs during capillary tube formation $(37,38)$. In subsequent studies, it has been proposed that 8Br-cAMP treatment upregulates the proliferation of capillary endothelial cells and the lumen formation $(39,40)$. The suggested molecular mechanism is increased $\mathrm{N}$-glycosylation of cellular 
glycoproteins (e.g., eFactor VIIIc) by accelerating the synthesis and turnover of $\mathrm{Glc}_{3} \mathrm{Man}_{9} \mathrm{GlcNAc}_{2}$-PP-Dol (lipid-linked oligosaccharide, LLO). Enhanced synthesis and turnover $\left(t_{1} / 2\right)$ of LLO correlates with increased mannosylphospho dolichol synthase (DPMS) activity in the endoplasmic reticulum (ER). cDNA cloning of Dpm1 gene identifies a cAMP-dependent protein kinase (PKA) mediated phosphorylation motif in the capillary endothelial cell DPMS (41).

\section{Study Design}

High expression of some glycosyl epitopes promotes invasion and metastasis, leading to shorter 5-10 year survival rates of patients. Whereas, expression of some other glycosyl epitopes suppress tumor progression, leading to higher post-operative survival rates $(42,43)$. The former category of epitopes include $\beta 6 \mathrm{GlcNAc}$ branching in N-linked structure; and the latter category includes $\beta 4 \mathrm{GlcNAc}$ competitive with $\beta 6 \mathrm{GlcNAc}$. The expression mechanism of these glycosyl epitopes in terms of status of respective glycosyltransferase genes has been extensively studied $(44,45)$. Unfortunately, due to the lack of a systematic study these results cannot be used to develop a new therapy.

Aberrant glycosylation occurs in essentially all types of experimental and human cancers, and many glycosyl epitopes constitute tumor-associated carbohydrate antigens (TACA, 46). A long-standing debate has been whether it is a result or a cause of cancer. Many recent studies indicate with no reasoning that aberrant glycosylation is a result of initial oncogenic transformation, as well as a "key" event in induction of invasion and metastasis. In current cancer research, glycosylation promoting or inhibiting tumor cell invasion and metastasis is of crucial importance $(46,47)$. This area has received much less attention from most cell biologists involved in cancer research, mainly because structural and functional concepts of glycosylation in cancer were more difficult to understand than the functional role of certain proteins and their genes in defining cancer cell phenotypes. The focus is now shifting because of emerging technologies on functional glycomics (http:// www.functionalglycomics.org) developed by the Consortium of Functional Glycomics and is being supported further by the initiatives from the US National Research Council, US National Academy of Sciences, and the National Cancer Institute. Therefore, our objective has been to test a transformative idea that inhibiting $\mathrm{N}$-acetylglucosaminyl 1-phosphate transferase (GPT) with a 840 dalton glucosamine-containing pyrimidine nucleoside (i.e., tunicamycin) we could inhibit angiogenesis and consequently the breast tumor growth. The significance of this innovative study is to target the protein $\mathrm{N}$-glycosylation machinery of the tumor microvasculature and develop a glycotherapy to be used in the clinic.

\section{Results and Discussion}

\section{Tunicamycin inhibits angiogenesis in vitro and decreases invasion and chemotaxis}

A non-transformed capillary endothelial cell line was used as a model. The cells had a population doubling time of 68 hours at $2 \%$ serum which reduced to 56 hours in the presence of high serum (i.e., 10\%) or other growth stimulants such as vascular endothelial growth factor (VEGF), basic fibroblast growth factor (FGF-2), 8Br-cAMP, etc. (48-50). Flow cytometric analysis of the cell cycle indicated that the change in population doubling 
was due to reduction of G1 phase. A synchronized culture of cells when treated with tunicamycin $(1 \mu \mathrm{g} / \mathrm{ml})$, it exhibited inhibition of cellular proliferation in a time and dosedependent manner (51). The $\mathrm{IC}_{50}$ for tunicamycin was $438 \mathrm{ng}$ when treated for 48 hours, it however changed to $235 \mathrm{ng}, 100 \mathrm{ng}$ and $85 \mathrm{ng}$ when treated for 72 hours, 96 hours and 120 hours, respectively (Figure 1a). There was a considerable loss of cellular morphology. In addition, the cells exhibited reduction in volume (i.e., cell shrinkage, chromatin condensation, picnotic appearance and the cytosol was full of apoptotic bodies (Figure 1b). Interestingly, the cells failed to recover following tunicamycin treatment. The recovery may be quantitative if treated for 24 hours at concentrations of $10 \mathrm{ng}, 1 \mu \mathrm{g}$, or $10 \mu \mathrm{g}$ but it was approximately $33 \%$ if the treatment was for 48 hours, and after 72 hours the recovery was extremely poor, i.e., between $8-10 \%$ (Figures $2 \mathrm{a}$ ). This was also analyzed by studying their colony forming ability. The cells lost their colony forming ability whether treated for 3 hours or 32 hours with tunicmycin $(1 \mu \mathrm{g} / \mathrm{ml})$ (Figure $2 \mathrm{~b})$.

\section{Tunicamycin-treated cells undergo nuclear fragmentation}

Reduction of cellular proliferation is associated with either a cell cycle arrest or a cell death or a combination of both. In our earlier study (48).

, we have observed not only there was a cell cycle arrest in G1 but also a loss in cell numbers with time due to cell death in tunicamycin-treated capillary endothelial cells. To evaluate the nature of cell death we stained the nuclei from control and tunicamycin (1 $\mu \mathrm{g} / \mathrm{ml})$ treated cells with Hoechst $33528(10 \mu \mathrm{g} / \mathrm{ml}$ in PBS, pH 7.2) and examined them under a fluorescence microscope. The photomicrographs of the nuclei from tunicamycintreated cells exhibited fragmentation (arrows) with no changes in untreated controls (Figure 3). Thus, confirming tunicamycin induced apoptosis (i.e., programmed cell death) in capillary endothelial cells.

\section{Tunicamycin inhibition of capillary endothelial cell proliferation is not reversible by FGF-2 or VEGF 165}

To evaluate the stability of the anti-angiogenic effect of tunicamycin in tumor microenvironment, a time course was set up where capillary endothelial cells were treated with tunicamycin $(1 \mu \mathrm{g} / \mathrm{ml})$ in the presence of FGF-2 $(10 \mathrm{ng} / \mathrm{ml})$ or $\operatorname{VEGF}_{165}(10 \mathrm{ng} / \mathrm{ml})$. The cells were monitored every $12 \mathrm{~h}$ for $108 \mathrm{~h}(\mathrm{FGF}-2)$ or $24 \mathrm{~h}$ for $144 \mathrm{~h}\left(\mathrm{VEGF}_{165}\right)$. Exogenous addition of FGF-2 or VEGF 165 stimulated cell proliferation, but they failed to protect the cells from the growth inhibitory effect of tunicamycin (Figure $4 a \& b$ ). The inhibition of cell proliferation was less in first $24 \mathrm{~h}$ of FGF-2 or VEGF 165 treatment but from $48 \mathrm{~h}$ onwards neither FGF-2 nor $\mathrm{VEGF}_{165}$ showed any protection $(\mathrm{p}<0.001)$.

\section{Tunicamycin down-regulates phospho-VEGFR1 and phospho-VEGFR2 receptors}

VEGF-induced changes are expected to be seen in cells expressing functional VEGF receptors (50). Endothelial cells express both VEGFR1 and VEGFR2 receptors although the VEGFR2 receptor has been claimed to be more effective in inducing angiogenesis. The status of total, phosphorylated VEGFR1 and VEGFR2 receptors and their ratios in capillary endothelial cells were evaluated in tunicamycin $(1 \mu \mathrm{g} / \mathrm{ml})$ treated cells. Total VEGFR1 expression was $\sim 97.2 \%, \sim 83.3 \%$, and $\sim 89.4 \%$ at $3 \mathrm{~h}, 12 \mathrm{~h}$, and $32 \mathrm{~h}$, respectively, over the 
synchronized cells, i.e. 0 h. These values for VEGFR2 were $\sim 110.3 \%, \sim 91.8 \%$, and $\sim 68.3 \%$, respectively, for the same time period. The level of phosphorylated VEGFR1 was down-regulated by $\sim 30.5 \%, \sim 33.5 \%$, and $\sim 75.7 \%$ in cells treated with tunicamycin for $3 \mathrm{~h}$, $12 \mathrm{~h}$, and $32 \mathrm{~h}$, respectively compared with untreated controls. The phosphorylated VEGFR2 was down-regulated by $\sim 44.4 \%$, and $\sim 72.6 \%$ in cells treated with tunicamycin for 3 and 32 $\mathrm{h}$, respectively but increased by $\sim 3.3 \%$ in cells treated with tunicamycin for $12 \mathrm{~h}$ (Figures $5 \mathrm{a} \& \mathrm{~b})$ compared with controls. Interestingly, the reduction of phosphorylated VEGFR1 (i.e., $\sim 30.5 \%$ ) and VEGFR2 (i.e., $\sim 44.4 \%$ ) was serendipitously very similar to $46.6 \%$ reduction of protein tyrosine kinase activity following $\mathrm{VEGF}_{165}$ stimulation in cells treated with tunicamycin for $3 \mathrm{~h}$ (Figure 5c). There was also a 1.6-2.4-fold reduction of phosphorylated VEGFR1 and VEGFR2 in cells treated with tunicamycin for $32 \mathrm{~h}$ over that of $3 \mathrm{~h}$. On the other hand, there was a 2.7-2.9-fold difference between the ratio of downregulated phospho-VEGF receptors (i.e. VEGFR1 and VEGFR2) and the total VEGFR 1 and VEGFR2 at 3 and $32 \mathrm{~h}$ of tunicamycin treatment (Table 1).

\section{Tunicamycin down-regulates phosphotyrosine kinase activity in VEGF $_{165}$-treated capillary endothelial cells}

VEGF signals through activation of tyrosine kinase $(52,53)$. We have examined the status of VEGF-stimulated tyrosine kinase activity in cells treated with tunicamycin. Cells stimulated with $\mathrm{VEGF}_{165}$ exhibited an increase in tyrosine kinase activity over the basal level. A marked reduction in the enzyme activity $(\mathrm{p}<0.001)$ however, was observed in cells treated with tunicamycin for $3 \mathrm{~h}$ (Figure $5 \mathrm{c}$ ). To evaluate the specificity of $\mathrm{VGF}_{165}$-stimulated upregulation of the tyrosine kinase activity, a 17 amino acid peptide, CBO-II (50 $\mu \mathrm{M})$, which blocks the binding of $\mathrm{VEGF}_{165}$ to its receptors, was used. Cells pretreated with $\mathrm{CBO}-\mathrm{II}$ inhibited the tyrosine kinase activity following VEGF $_{165}$ stimulation $(\mathrm{p}<0.001)$ to an extent similar to that observed in tunicamycin-treated cells. No further reduction in $\mathrm{VEGF}_{165^{-}}$ stimulated activity was observed when tunicamycin treated cells were preincubated with CBO-II (Figure 5c). This suggested no changes in the receptor level, but alteration in its signaling ability.

\section{Tunicamycin treatment decreases invasion and chemotaxis of capillary endothelial cells and inhibits angiogenesis in vivo}

Capillary proliferation and tissue invasion are important for solid tumor progression. We have studied the Matrigel ${ }^{\mathrm{TM}}$ invasion of capillary endothelial cells as well as their chemotactic activity in the presence or absence of tunicamycin. Invasion through the transwell membrane in control plate (Figure 6aA) remained almost the same, whereas those migrated through the Matrigel ${ }^{\mathrm{TM}}$ reduced significantly in the presence of tunicamycin (Figure 6aB, far right; $\mathrm{p}<0.001$ ). This supported that tunicamycin makes capillaries less capable of invading the extracellular matrix. In addition to measuring the invasion character, the cells were also tested for their chemotaxis, i.e. the migratory activity on a wounded surface. The rate of migration was $\sim 75 \%$ higher in the presence of $\mathrm{VEGF}_{165}$. In the presence of tunicamycin, it was only $\sim 60 \%$ of the control and was further reduced (i.e., $\sim 25 \%$ ) when both tunicamycin and $\mathrm{VEGF}_{165}$ were present (Figure $6 \mathrm{aC}$, far right; $\mathrm{p}<0.001$ ).

Adv Exp Med Biol. Author manuscript; available in PMC 2015 October 13. 
To study the anti-angiogenic effect of tunicamycin in vivo, we have used the Matrigel ${ }^{\mathrm{TM}}$ plug assay in nude mice. Angiogenesis was induced by injecting Matrigel ${ }^{\mathrm{TM}}$ containing $\mathrm{VEGF}_{165}$. Intense vascularization was observed 10 days post-implantation in Matrigel ${ }^{\mathrm{TM}}$ plugs containing $\mathrm{VEGF}_{165}$. In contrast, the plugs with Matrigel $^{\mathrm{TM}}$ alone appeared pale. Tunicamycin inhibited neo-vascularization, and the plugs appeared pale as well even when VEGF $_{165}$ was present [Figure 6(b)A]. Histological analysis of H\&E-stained paraffin sections also supported an increased number of vessels in the plugs containing VEGF $_{165}$, as opposed to the plugs with Matrigel ${ }^{\mathrm{TM}}$ alone. Tunicamycin treatment caused considerable reduction of neo-vascularization in the plugs containing VEGF 165 [Figure 6(b)B].

Quantitative analysis supported $\sim 75 \%$ reduction in the vessel density in tunicamycin treated Matrigel $^{\mathrm{TM}}$ plugs [Figure 6(b)B far right; $\mathrm{p}<0.001$ ].

Microvessel density is a vital prognostic biomarker correlating the growth and development of the tumor (54) and is often used to evaluate the tumor growth (55). To assess the tunicamycin-mediated inhibition of vessel formation in Matrigel ${ }^{\mathrm{TM}}$ plugs, the microvessel density in the plugs was examined immunohistochemically after staining for CD34 and CD144. Microscopic examination revealed numerous CD34- and CD144-stained vessels in the positive control group $\left(\mathrm{VEGF}_{165}\right.$ + heparin) [Figure 6(b)C; left to right], but only a few vessels in the group treated with tunicamycin [Figure 6(b)C; right]. $87 \pm 4.04$ vessels stained for CD34 and $78 \pm 3.4$ vessels for CD144 in the positive control group as opposed to only $12 \pm 1.2$ vessels in CD34 or $8 \pm 1.5$ vessels in CD144 in the group treated with tunicamycin, respectively. Quantification [Figure 6(b)D] indicates $\sim 87.5 \%$ decrease $(\mathrm{p}<0.001)$ in microvessel density because of tunicamycin treatment.

\section{Tunicamycin inhibits breast tumor growth in athymic nude mice}

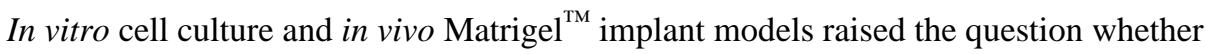
tunicamycin could successfully treat breast tumors. To answer, we took the following approaches: (i) developing orthotopic breast tumor in nude mice with MDA-MB-435 $\left(\mathrm{ER}^{-} / \mathrm{PR}^{-} / \mathrm{EGFR}^{+}\right.$) cells and treating with tunicamycin by intravenous injection (group a; Figure. 7); and (ii) developing breast tumor xenografts in nude mice with MDA-MB-231 $\left(\mathrm{ER}^{-} / \mathrm{PR}^{-} / \mathrm{EGFR}^{-}\right.$) cells and treating with tunicamycin orally (group $b$; Figure 7). In group a, tunicamycin treatment was started after the tumor size reached $\sim 3 \mathrm{~mm}$ in diameter in 6 days at doses of $0.1,0.5$, and $1.0 \mathrm{mg} / \mathrm{kg}$, respectively, once a week. The results (Figure 7A) indicated that tumor growth progressed in untreated controls and also in the group treated with a low dose of tunicamycin (i.e. $0.1 \mathrm{mg} / \mathrm{kg}$ ). However, it was markedly reduced $(\sim 56 \%$ in 23 days) when treated with $1.0 \mathrm{mg} / \mathrm{kg}$ of tunicamycin. Tumor volume regressed $\sim 17 \%$ at $0.5 \mathrm{mg} / \mathrm{kg}$ of tunicamycin. It is important to note that 15 times more taxol was needed to match the effect of $1 \mathrm{mg} / \mathrm{kg}$ of tunicamycin. The histogram in Figure 7A (far right) recorded the tumor weight after each treatment and at the end of the treatment period. H\&E staining of paraffin sections of the tumor tissue indicated reduced microvascular density as the tunicamycin concentrations were increased from zero to $1 \mathrm{mg} / \mathrm{kg}$ (Figure 7, B and C). Figure 7C (far right) recorded the mitotic index of tumor cells per 10 high power field (HPF) and explained that the mitotic index of the tumor cells declined as a consequence of tunicamycin treatment ( $\mathrm{p}<0.001)$. Ki-67 and VEGF expressions were reduced following tunicamycin treatment (Figure D\&E). In group $b$, tunicamycin treatment was started 7 days after tumor 
development and was given orally twice a week at a dose of $5 \mu \mathrm{g} / \mathrm{mouse}(\approx 0.25 \mathrm{mg} / \mathrm{kg})$. In the control group [Figure $7(1 \& 2)$ ], the tumor growth almost doubled in 4 weeks, whereas the growth in the treatment group the growth was reduced by $\sim 65 \%$ in 1 week and maintained [Figure 7 (3\&4)]. Graphical representation of the observation is in the panel below.

\section{Surface expression of $\mathrm{N}$-glycans on tumor microvasculature and the development of unfolded protein response in tumor microvasculature}

Tunicamycin inhibits LLO biosynthesis and consequently the glycosylation of N-linked glycoproteins. To verify the status of the $\mathrm{N}$-glycans on the breast tumor microvascular endothelial cells, the tissue sections were stained with Texas-Red conjugated WGA and examined under a fluorescence microscope. Tumor microvessels in untreated controls were stained markedly but the staining intensity per vessel was reduced almost $50 \%$ upon treating with tunicamycin [Figure 8(a) A]. This was further confirmed by quantifying the images with NIH-IMAGE J program (Figure 8b). Tumor cells from untreated control (Figure 8(a)B) exhibited positive WGA staining but the intensity was much less than the endothelial cells. Furthermore, tunicamycin treatment caused a morphological change on tumor cells, and the WGA staining was not only reduced but appeared amorphous.

Inhibition of $\mathrm{N}$-glycan biosynthesis with tunicamycin develops ER stress-mediated upr (56). This led us to investigate whether ER stress-mediated upr exists in breast tumor microvasculature of the mice receiving tunicamycin. Tumor tissue is heterogeneous. To answer the question, the tumor microvascular endothelial cells were first identified by staining for CD144 (green fluorescence; a marker for endothelial cells) and then stained for the GRP-78 (red fluorescence), an ER chaperone. In untreated control, CD144-stained endothelium appeard as a thin line around the vessel as did the GRP-78 (Figure 8(a) C and D). But, as the tumors were treated with tunicamycin, a high level expression of GRP-78 was observed in microvascular endothelial cells of the tumor (Figure 8(a) D). CD144 also stained the same area (Figure 8(a) C). Both green and red fluorescence of CD144 and GRP-78 co-localized in tumor microvasculature and supported unfolded protein response mediated by ER stress. GRP-78 staining in tumor cells following tunicamycin treatment appeared to be increased (Figure 8(a) E). This may be an indirect effect because of nutritional deprivation due to reduced blood flow in the tumor and not necessarily due to an induction of $u p r$.

\section{Raman spectroscopy of control and tunicamycin-treated capillary endothelial cells}

About one-third of newly synthesized proteins translocate to the lumen of the ER where they are subject to post-translational modifications and folded into correct 3D structures before being targeted to various cellular organelles or transported to the surface of the cell. This process is highly sensitive to alterations in the ER luminal environment. Among the variety of insults that disrupt protein folding in the ER lumen and activate the upr, the most notable chemical inducer is the protein $\mathrm{N}$-glycosylation inhibitor tunicamycin. There is no established analytical tool currently available to detect the ER stress-mediated upr. Because Raman spectroscopy targets protein conformation, we have used Raman Spectroscopy here to assess the cellular milieu following tunicamycin treatment. The spectra were collected 
from capillary endothelial cells after culturing them in the presence or absence of tunicamycin $(1 \mu \mathrm{g} / \mathrm{ml})$ for 3 and $12 \mathrm{~h}$. Figures $8 \mathrm{c} \& d$; upper panel) display the spectra in cells cultured for $3 \mathrm{~h}$ and $12 \mathrm{~h}$ in the absence of tunicamycin. The inset is an enlarged 1700-1600 $\mathrm{cm}^{-1}$ region showing bands at 1694,1684 , and $1672 \mathrm{~cm}^{-1}$, respectively. These bands originate mainly from the $\mathrm{C}=\mathrm{O}$ stretch of mono-substituted amides as in proteins $(57,58)$. The spectral band near $1650 \mathrm{~cm}^{-1}$ is characteristic of proteins in their secondary and/or tertiary structures (the amide I band). For example, Raman spectra of a-helices peak around $1655 \mathrm{~cm}^{-1}$, but those of $\beta$-sheets peak around $1670 \mathrm{~cm}^{-1}(58)$. The band at $1672 \mathrm{~cm}^{-1}$ in the spectra obtained in this study may originate from disordered a-helices (58), but the ones at 1684 and $1694 \mathrm{~cm}^{-1}$ certainly arise from completely disordered protein chains (58). The intensities of these bands decreased significantly, when the cells are cultured in the presence of tunicamyin (Figure 8c; panel below), the $\mathrm{C}=\mathrm{O}$ moieties of their amide groups are not energetically suitable to absorb infrared light in the $1700-1600 \mathrm{~cm}^{-1}$ region. The Raman spectra of cells cultured for $12 \mathrm{~h}$ without tunicamycin showed typical protein bands; those in the $1700-1600 \mathrm{~cm}^{-1}$ region are enlarged in the inset (Figure 8d; panel below). The intensities of these bands, however, decreased significantly when the cells were cultured in the presence of tunicamycin $(1 \mu \mathrm{g} / \mathrm{ml}$; Figure 8d, TM). Table 2 summarizes the details of these results (59).

\section{Effect of tunicamycin nanoparticles on in vitro angiogenesis}

Gold nanoparticles (Au NPs) were synthesized by using wet chemical methods (60). The average diameter of the Au NPs used for functionalization with tunicamycin was $20 \mathrm{~nm}$. The scheme for attachment of tunicamycin to the Au NPs is shown in Figure 9a. To study the cell viability synchronized culture of capillary endothelial cells were incubated either with native tunicamycin $(1 \mu \mathrm{g} / \mathrm{ml})$ or with tunicamycin nanoparticles for $1 \mathrm{~h}$ at $37^{\circ} \mathrm{C}$ in a $\mathrm{CO}_{2}$ incubator $\left(5 \% \mathrm{CO}_{2}\right.$ and $95 \%$ air) in 96-well microtiter plates. At the end, the plates were processed for the MTT assay. The results (Figure 9c) indicate that the cell viability was reduced to almost $50 \%(\mathrm{P}<0.001)$ when treated with tunicamycin conjugated to 20 or $50 \mathrm{~nm}$ gold particles. Native tunicamycin under similar condition had no effect. Importantly, both tunicamycin nanotubes and nanoparticles were equally effective in reducing the cell proliferation.

To evaluate, if tunicamycin nanoparticles would induce "ER stress" as the native tunicamycin does, a synchronized population of capillary endothelial cells were treated with various nano-formulated tunicamycin as well as with native tunicamycin just for $1 \mathrm{~h}$. We have analyzed the GRP-78/Bip expression by western blotting as a quantitative measure of "ER stress". Our results indicate that GRP-78/Bip expression was down regulated by $\sim 28 \%$ in cells treated with native tunicamycin, i.e., no detectable "ER stress". The effect of $20 \mathrm{~nm}$ gold bound to tunicamycin nanotubes was neutral. On the other hand, the GRP-78/Bip expression was increased by $\sim 126-186 \%$ in cells treated with tunicamycin nanotubes, and 20 or $50 \mathrm{~nm}$ gold bound to tunicamycin, respectively over the control (Figure 9d).

"ER stress" is associated with apoptotic death of a cell. Since, activation of pro-caspase 9 to caspase-9 in the aptosome is the initiation of the apoptotic process and the process is concluded by the activation of caspase-3, tunicamycin nano-formulations were tested against 
caspase- 9 and caspase 3 expressions. The evidences presented here have directed our attention towards the apoptotic death of the cells treated with tunicamycin nanoformulations. The expression of caspase- 9 was down regulated $(\mathrm{p}<0.001)$ in cells treated with all tunicamycin nano-formulations with no change with native tunicamycin (Figure 9e\&f). It was selective in the case of caspase-3. The down regulation was markedly enhanced ( $\mathrm{p}<0.001$ ) with $50 \mathrm{~nm}$ tunicamycin nanoparticles, $100 \mathrm{~nm}$ tunicamycin gold nanoparticles, and $20 \mathrm{~nm}$ Tunicamycin Au NPs (Figure 9f).

\section{Conclusion and Future Direction}

The asparagine-linked protein glycosylation inhibitor tunicamycin targets GlcNAc 1-P transferase and reduces angiogenesis in vitro and in vivo. It is also reduces the progression of double and triple negative breast tumors in nude mice. Importantly, the tunicamycin action survives in tumor microenvironment, and the treated cells do not regain their virulence even after tunicamycin is withdrawn. Tunicamycin gold nanoparticles are three times more potent that its native formulation and the reduction of cellular proliferation in the presence of these nanaoparticles is not associated with apoptosis.

Considering the tunicamycin's ability to inhibit both angiogenesis and the tumor cells alike, we are convinced that tunicamycin will be effective against any solid tumor serving the concept "one size fits all". But, certainly more work is needed towards the proposed hypothesis.

\section{Acknowledgments}

The work was supported in whole or in part, by Susan G. Komen for the Cure BCTR0600582 (to D.K.B.) and NIH/ NIMHD 2G12MD007583 (to K.B.)

\section{References}

1. Jemal A, Siegel R, Ward E, Murray T, Xu J, Smigal C, Thun J. Cancer Statistics. CA-A Cancer J Clin. 2006; 56:106-130.

2. Berkowitz, GS.; Kelsey, JL. Epidemiology of breast cancer. In: Marchant, DJ., editor. Diagnosis and Management of Breast Cancer. Elsevier; New York: 2006.

3. Cleator S, Heller W, Coombes RC. Triple-negative breast cancer: therapeutic options. Lancet Oncol. 2007; 8:235-244. [PubMed: 17329194]

4. Rhee J, Han SW, Oh DY, Kim JH, Im SA, Han W, Park IA, Noh DY, Bang YJ, Kim TY. The clinicopathologic characteristics and prognostic significance of triple-negativity in node-negative breast cancer. BMC Cancer. 2008; 8:307. [PubMed: 18947390]

5. Carey LA, Perou CM, Livasy CA, Dressler LG, Cowan D, Conway K, Karaca G, Troester MA, Tse CK, Edmiston S, Deming SL, Geradts J, Cheang MC, Nielsen TO, Moorman PG, Earp HS, Millikan RC. Racce, breast cancer subtypes, and survivaal in the Caarolina Breast Study. JAMA. 2006; 295:2492-2502. [PubMed: 16757721]

6. Livasy CA, Karaca G, Nanda R, Tretiakova MS, Olopade OI, Moore DT, Perou CM. Phenotypic evaluation of the basal-like subtype of invasive breast carcinoma. Mod Pathol. 2006; 19:264-271. [PubMed: 16341146]

7. Aksoy S, Dizdar O, Harputluoglu H, Altundag K. Demographic, clinical, and pathological characteristics of Turkish triple-negative breast cancer patients: single center experience. Ann Oncol. 2007; 18:1904-1906. [PubMed: 17993632]

8. Van Calster B, Vanden Bempt I, Drijkoningen M, Pochet N, Cheng J, Van Huffel S, Hendrickx W, Decock J, Huang HJ, Leunen K, Amant F, Berteloot P, Paridaens R, Wildiers H, Van Limbergen E, 
Weltens C, Timmerman D, Van Gorp T, Smeets A, Van den Bogaert W, Vergote I, Christiaens MR, Neven P. Axillary lymph node status of operable breast cancers by combined steroid receptor and HER-2 status: triple positive tumours are more likely lymph node positive. Breast Cancer Res Treat. 2009; 113:181-187. [PubMed: 18264760]

9. Dent RD, Trudeau M, Pritchard KI, Hanna WM, Kahn HK, Sawka CA, Lickley LA, Rawlinson E, Sun P, Narod SA. Triple-negative breast cancer clinical features and patterns of recurrence. Clin Cancer Res. 2007; 13:4429-4434. [PubMed: 17671126]

10. Stockmans G, Deraedt K, Wildiers H, Moerman P, Paridaens R. Triple-negative breast cancer. Curr Opin Oncol. 2008; 20:614-620. [PubMed: 18841042]

11. Berkowitz, GS.; Kelsey, JL. Epidemiology of breast cancer. In: Marchant, DJ., editor. Diagnosis and Management of Breast Cancer. Elsevier; New York: 2006.

12. Kalluri R, Weinberg RA. The basics of epithelial-mesenchymal transition. J Clin Invest. 2009; 119:1420-1428. [PubMed: 19487818]

13. Ries, LAG.; Kosary, CKL.; Hankey, BF., et al. Natl Cancer Inst. Bethesda, MD, USA: 1999. SEER Cancer statistics review 1973-2996.

14. Sondik EJ. Breast cancer trends: incidence, mortality and survival. Cancer. 1994; 74:995-999. [PubMed: 8039156]

15. Forbes JF. The control of breast cancer: The role of tamoxifen. Seminars in Oncol. 1997; 24(Suppl 1):S15, S1-19.

16. Boring CC, Squires TS, Tong T. Cancer statistics. CA-A Cancer J Clin. 1991; 41:19-39.

17. Kelsey JL, Gammon MD. The epidemiology of breast cancer. CA-A Cancer J Clin. 1991; 41:146165.

18. Lynn AG, Ries MS. Top 5 cancers for females and males in the US. J Natl Cancer Inst. 1995; $87: 867$.

19. Hortobagyl GN, Buzdar AU. Current status of adjuvant systemic therapy for primary breast cancer: progress and controversy. CA-A Cancer J Clin. 1995; 45:199-226.

20. Folkman J. What is the evidence that tumors are angiogenesis dependent? J Natl Cancer Res. 1990; 82:4-6.

21. Broomhall SR, Hallissey MT, Whiting J, Scholefield J, Tierney G, Stuart RC, Hawkins RE, McCulloch P, Maughan T, Brown PD, Baillet M, Fielding JW. Marimastat as maintenance therapy for patients with advanced gastric cancer: a randomised trial. Br J Cancer. 2002; 86:1864-1870. [PubMed: 12085177]

22. Erlichman C, Adjei AA, Alberts SR, Sloan JA, Goldberg RM, Pitot HC, Rubin J, Atherton PJ, Klee GG, Humphrey R. Phase I study of the matrix metalloproteinase inhibitor, BAY 12-9566. Ann Oncol. 2001; 12:389-395. [PubMed: 11332153]

23. Rudek MA, Figg WD, Dyer V, Dahut W, Turner ML, Steinberg SM, Liewehr DJ, Kohler DR, Pluda JM, Reed E. Phase I clinical trial of oral COL-3, a matrix metalloproteinase inhibitor, in patients with refractory metastatic cancer. J Clin Oncol. 2001; 19:584-592. [PubMed: 11208854]

24. Fotsis T, Zhang Y, Pepper MS, Adlercreutz H, Montesano R, Nawroth PP, Schweigerer L. The endogenous oestrogen metabolite 2-methoxyoestradiol inhibits angiogenesis and suppresses tumour growth. Nature. 1994; 368:237-239. [PubMed: 7511798]

25. Klauber N, Parangi S, Flynn E, Hamel E, D'Amato RJ. Inhibition of angiogenesis and breast cancer in mice by the microtubule inhibitors 2-methoxyestradiol and taxol. Cancer Res. 1997; 57:81-86. [PubMed: 8988045]

26. Uhr JW, Scheuermann RH, Street NE, Vitetta ES. Nat med. 1997; 3:505-509. [PubMed: 9142117]

27. Gastl G, Hermann T, Steurer M, Zmija J, Gunsilius E, Unger C, Kraft A. Oncology. 1997; 54:177184. [PubMed: 9143396]

28. Folkman J. The role of angiogenesis in tumor growth. Semin Cancer Biol. 1992; 3:65-71. [PubMed: 1378311]

29. Banerjee DK. Microenvironment of endothelial cell growth and regulation of protein Nglycosylation. Indian J Biochem Biophys. 1988; 25:8-13. [PubMed: 3141265]

30. Oliveira CM, Banerjee DK. Role of extracellular signaling on endothelial cell proliferation and protein N-glycosylation. J Cellular Physiol. 1990; 144:467-472. [PubMed: 2202743] 
31. Tiganis T, Leaver DD, Ham K, Friedhuber A, Stewart P, Dziadek M. Functional and morphological changes induced by tunicamycin in dividing and confluent endothelial cells. Exp Cell Res. 1992; 198:191-200. [PubMed: 1309501]

32. Nguyen M, Folkman J, Bischoff J. 1-Deoxymannojirimycin inhibits capillary tube formation in vitro. Analysis of N-linked oligosaccharides in bovine capillary endothelial cells. J Biol Chem. 1992; 267:26157-26165. [PubMed: 1464626]

33. Banerjee DK, Vendrell-Ramos M. Is asparagine-linked protein glycosylation an obligatory requirement for angiogenesis? Indian J Biochem Biophys. 1993; 30:389-394. [PubMed: 7516308]

34. Nguyen M, Strubel NA, Bischoff J. A role for sialyl Lewis-X/A glycoconjugates in capillary morphogenesis. Nature. 1993; 365:267-269. [PubMed: 7690465]

35. Pili R, Chang J, parties RA, Mueller RA, Chrest FJ, Passaniti A. The alpha-glucosidase I inhibitor castanospermine alters endothelial cell glycosylation, prevents angiogenesis, and inhibits tumor growth. Cancer Res. 1995; 55:2920-2926. [PubMed: 7540952]

36. Ingber DE, Folkman J. How does extracellular matrix control capillary morphogenesis? Cell. 1989; 58:803-805. [PubMed: 2673531]

37. Nguyen M, Folkman J, Bischoff J. 1-Deoxymannojirimycin inhibits capillary tube formation in vitro. Analysis of N-linked oligosaccharides in bovine capillary endothelial cells. J Biol Chem. 1992; 267:26157-26165. [PubMed: 1464626]

38. Nguyen M, Strubel NA, Bischoff J. A role for sialyl Lewis-X/A glycoconjugates in capillary morphogenesis. Nature. 1993; 365:267-269. [PubMed: 7690465]

39. Colleoni M, Rocca A, Sandri MT, Zorzino L, Masci G, Nolè F, Peruzzotti G, Robertson C, Orlando L, Cinieri S, de BF, Viale G, Goldhirsch A. Low-dose oral methotrexate and cyclophosphamide in metastatic breast cancer: antitumor activity and correlation with vascular endothelial growth factor levels. Ann Oncol. 2002; 13:73-80. [PubMed: 11863115]

40. Banerjee DK. Microenvironment of endothelial cell growth and regulation of protein Nglycosylation. Indian J Biochem Biophys. 1988; 25:8-13. [PubMed: 3141265]

41. Baksi K, TavárezPagán JJ, Martínez JA, Banerjee DK. Unique Structural Motif Supports Mannosylphospho Dolichol Synthase: An Important Angiogenesis Regulator. Current Drug Targets. 2008; 9:262-271. [PubMed: 18393820]

42. Hakomori S. Tumor malignancy defined by aberrant glycosylation and sphingo(glyco)lipid metabolism. Cancer Res. 1996; 56:5309-5318. [PubMed: 8968075]

43. Muramatsu T. Carbohydrate signals in metastasis and prognosis of human carcinomas. Glycobiol. 1993; 3:291-296.

44. Wandall HH, Blixt O, Tarp MA, Pedersen JW, Bennett EP, Mandel U, Ragupathi G, Livingston PO, Hollingsworth MA, Taylor-Papadimitriou J, Burchell J, Clausen H. Cancer biomarkers defined by autoantibody signatures to aberrant O-glycopeptide epitopes. Cancer Res. 2010; 70:1306-1313. [PubMed: 20124478]

45. Taniguchi, N.; Honke, K.; Fukuda, M. Handbook of Glycosyltransferases and their elated Genes. Springer; Tokyo: 2002.

46. Cazet A, Julien S, Bobowski M, Burchell J, Delannoy P. Tumour-associated carbohydrate antigens in breast cancer. Breast Cancer Res. 2010; 12:204-220. [PubMed: 20550729]

47. Fuster MM, Esko JD. The sweet and sour of cancer: glycans as novel therapeutic targets. Nature Reviews. 2005; 5:526-542.

48. Martínez JA, TorresNegrón I, Amigó LA, Banerjee DK. Expression of Glc3Man9GlcNAc2-PPDol is a prerequisite for capillary endothelial cell proliferation. Cell Mol Biol (Noisy-le-grand). 1999; 45:137-152. [PubMed: 10099847]

49. Banerjee, DK.; Martinez, JA.; Baksi, K. Significance of protein N-glycosylation in breast tumor angiogenesis. In: Maragoudakis, ME.; Papadimitriou, E., editors. Angiogenesis: Basic Science and Clinical Applications. Transworld Research network; Trivandrum, Kerala, India: 2007. p. 281-301.

50. Banerjee A, Lang JY, Hung MC, Sengupta K, Banerjee SK, Baksi K, Banerjee DK. Unfolded protein response is required in nu/nu mice microvasculature for treating breast tumor with tunicamycin. J Biol Chem. 2011; 286:29127-29138. [PubMed: 21676868] 
51. Martínez JA, Torres-Negrón I, Amigó LA, Roldán RA, Mendéz A, Banerjee DK. Tunicamycin inhibits capillary endothelial cell proliferation by inducing apoptosis. Targeting dolichol-pathway for generation of new anti-angiogenic therapeutics. Adv Exp Med Biol. 2000; 476:197-208. 0. [PubMed: 10949666]

52. Zwick E, Bange J, Ullrich A. Receptor tyrosine kinase signalling as a target for cancer intervention strategies. Endocr Relat Cancer. 2001; 8:161-173. [PubMed: 11566607]

53. Robinson DR, Wu YM, Lin SF. The protein tyrosine kinase family of the human genome. Oncogene. 2000; 19:5548-5557. [PubMed: 11114734]

54. Kerbel RS. Tumor angiogenesis: past, present and the near future. Carcinogenesis. 2000; $21: 505-$ 515. [PubMed: 10688871]

55. Weidner N, Folkman J. Tumoral vascularity as a prognostic factor in cancer. Important Adv Oncol. 1996:167-190. [PubMed: 8791135]

56. Zhang K, Kaufman RJ. Signaling the unfolded protein response from the endoplasmic reticulum. J Biol Chem. 2004; 279:25935-2598. [PubMed: 15070890]

57. Carter, EA.; Edwards, HGM. Biological Applications of Raman Spectroscopy. In: Gremlich, HU.; Bing, Y., editors. Infrared and Raman Spectroscopy of Biological Materials. Marcel Deker, Inc; 2001. p. 421-475.

58. Sane SU, Cramer SM, Przybycien TM. A holistic approach to protein secondary structure characterization using Amide I Band Raman Spectroscopy. Analyt Biochem. 1999; 269:255-272. [PubMed: 10221997]

59. Longas MO, Kotapati A, Prasad KP, Banerjee A, Santiago J, Baksi K, Banerjee DK. Balancing life with glycoconjugates: monitoring unfolded protein response-mediated anti-angiogenic action of tunicamycin by Raman Spectroscopy. Pure Appl Chem. 2012; 84:1907-1918. [PubMed: 22936838]

60. Banerjee A, Johnson KT, Banerjee IA, Banerjee DK. Nanoformulation enhances anti-angiogenic efficacy of tunicamycin. Transl Cancer Res. 2013; 2:240-255. 


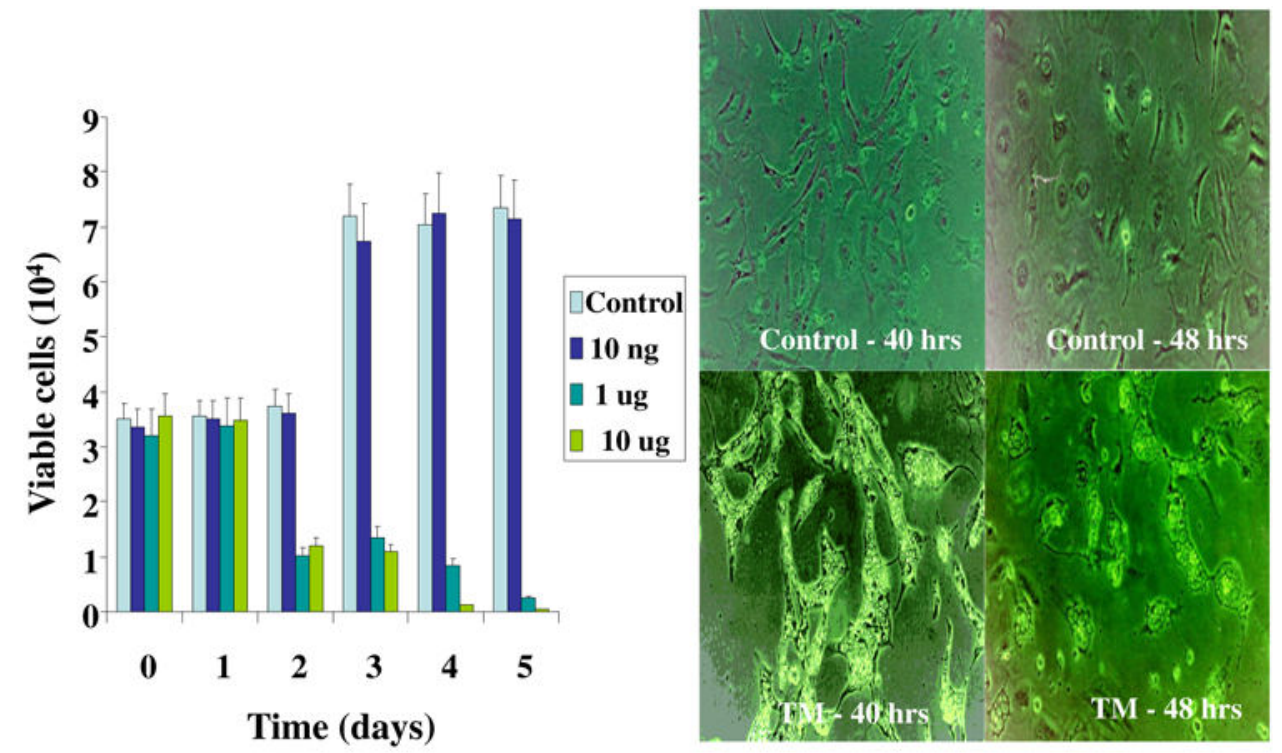

(a)

(b)

Figure 1.

Proliferation of capillary endothelial cells as a function of tunicamycin concentration and the time of treatment (a). Morphological changes associated with apoptotic death of microvascular endothelial cells following tunicamycin treatment (b) 

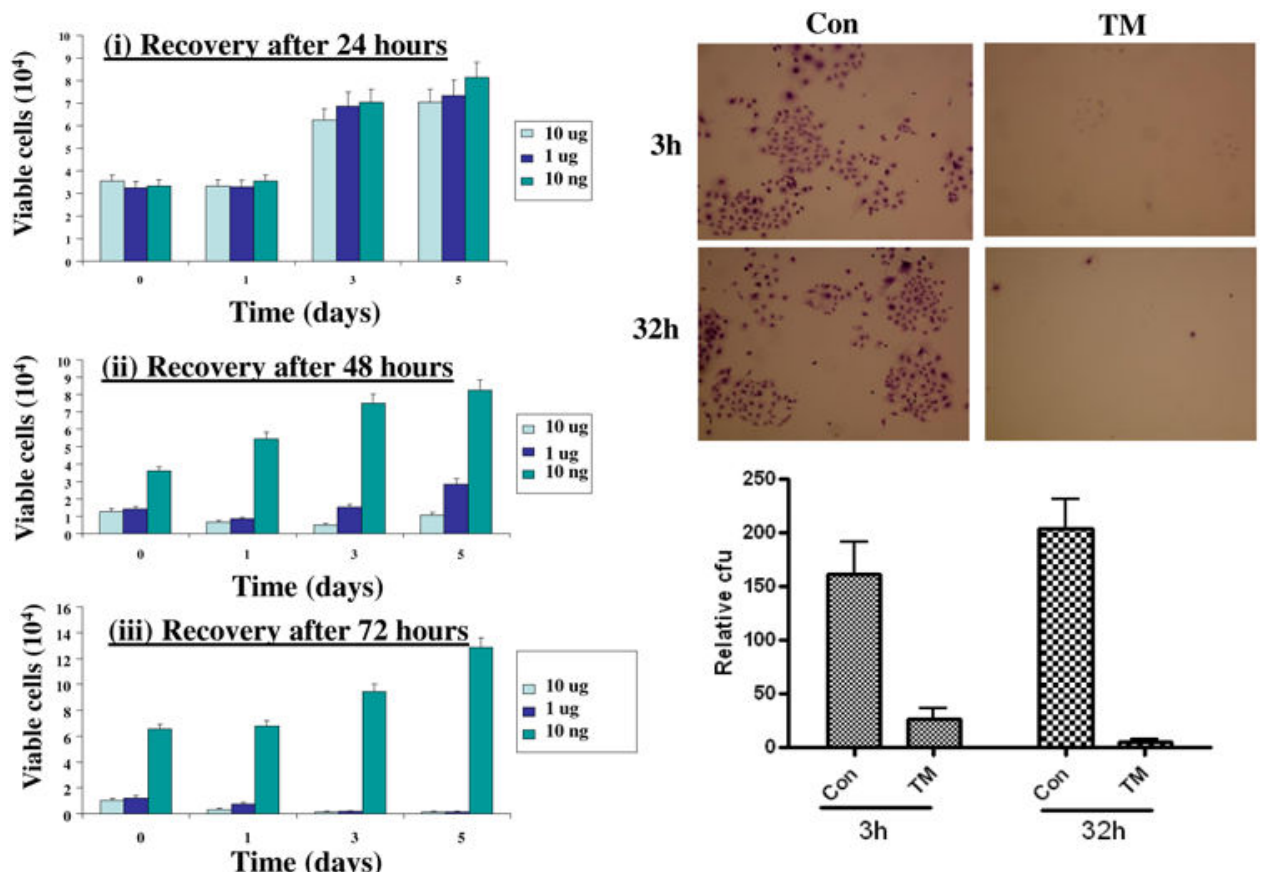

(a)

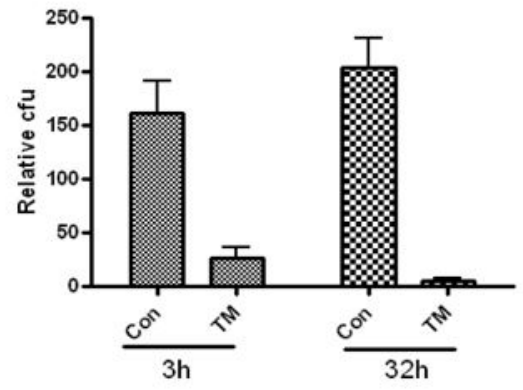

(b)

Figure 2.

The capillary endothelial cells do not regain their virulence upon withdrawal of tunicamycin. (a) Monitoring cell number after 24 hour, 48 hour and 72 hours. (b) Clonogenic assay. 
Control
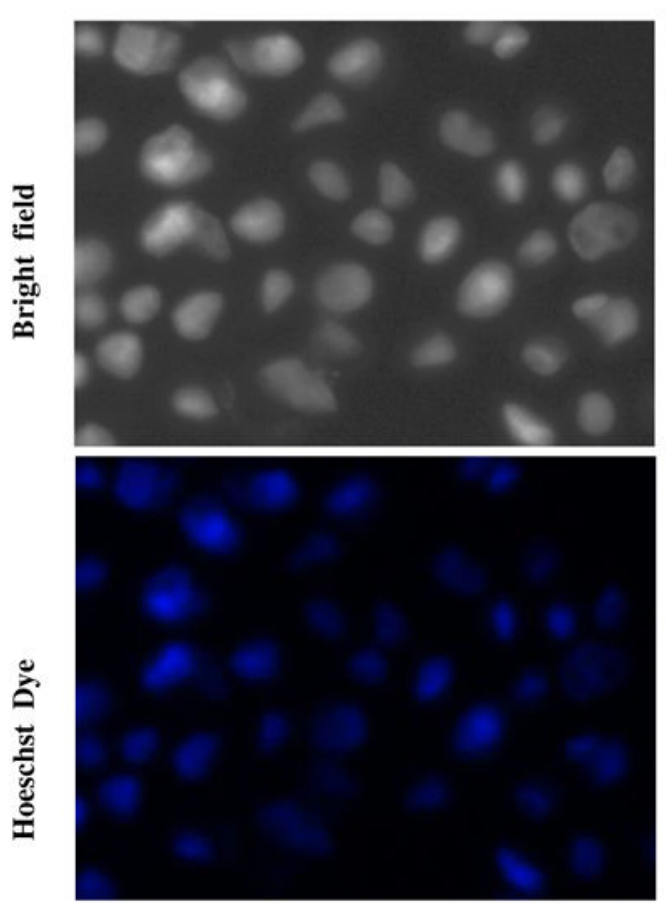

Figure 3.

Nuclear fragmentation of capillary endothelial cells following tunicamycin treatment.

TM
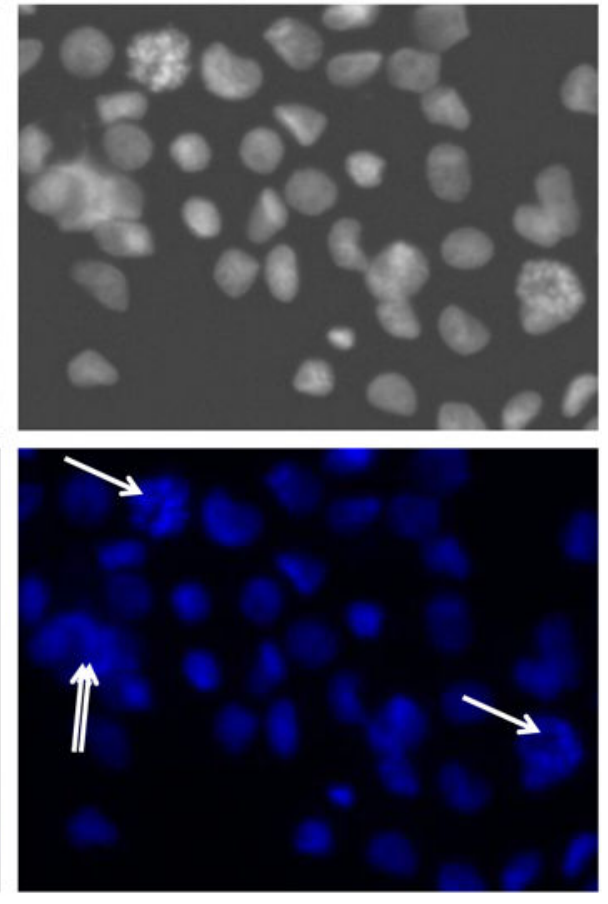

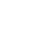




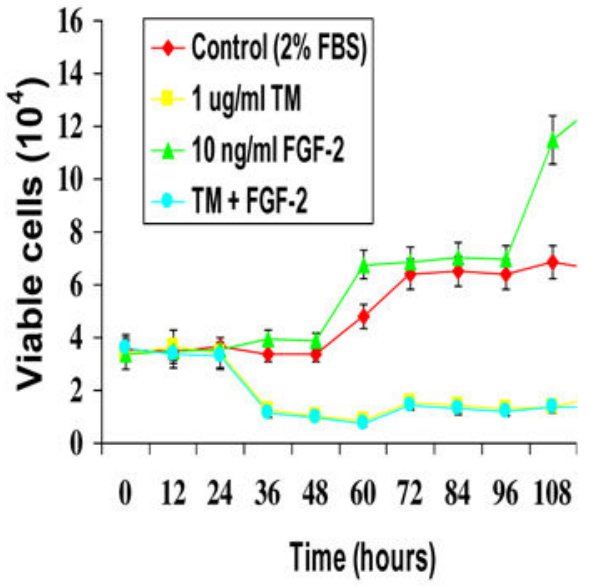

(a)

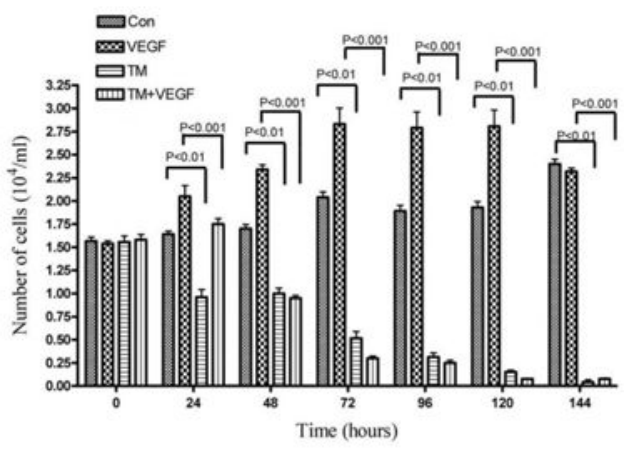

(b)

Figure 4.

Tunicamycin survives under tumor microenvironment. (a) in the presence of FGF-2; and (b) in the presence of $\mathrm{VEGF}_{165}$. 


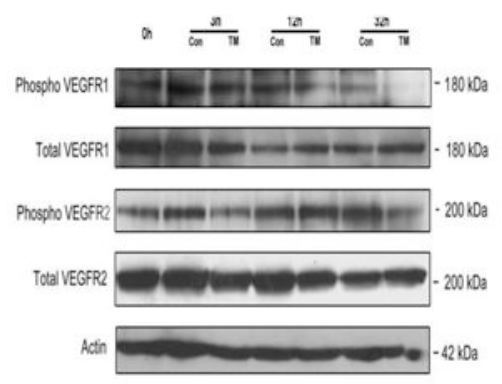

(a)
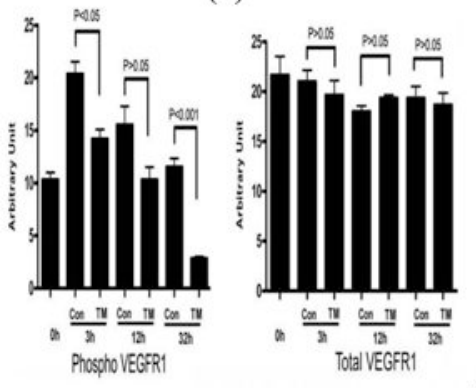

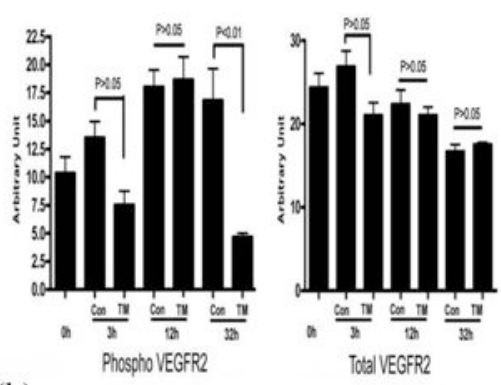

(b)

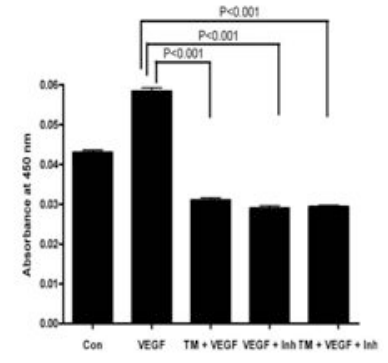

(c)

Figure 5.

Tunicamycin treatment down regulates VEGF receptors I \& II expression (a), phosphorylation of VEGFRI \& II (b) and $\mathrm{VEGF}_{165}$-specific protein tyrosine kinase (c). 

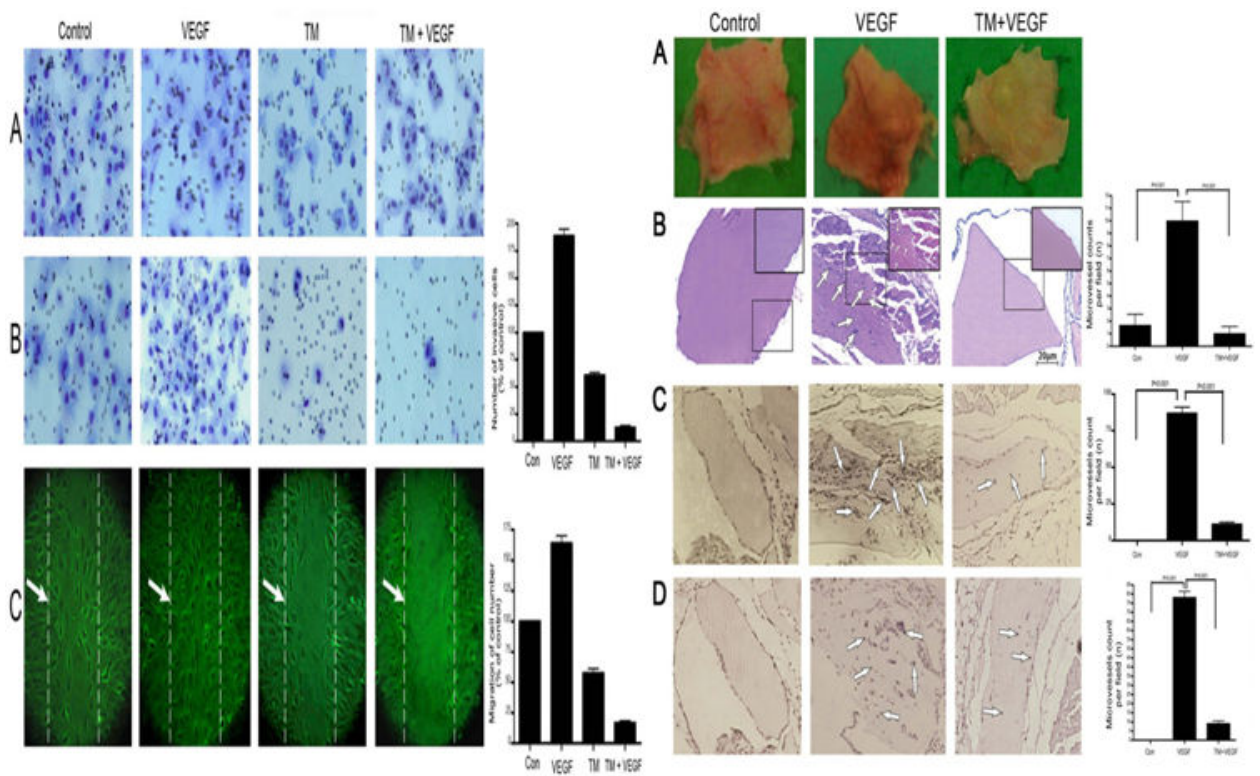

(a)

(b)

Figure 6.

Tunicamycin inhibits (a) migration and chemotaxis of capillary endothelial through Matrigel $^{\mathrm{TM}}$ matrices in a wound healing assay; (b) angiogenesis in Matrigel ${ }^{\mathrm{TM}}$ plug assay. 

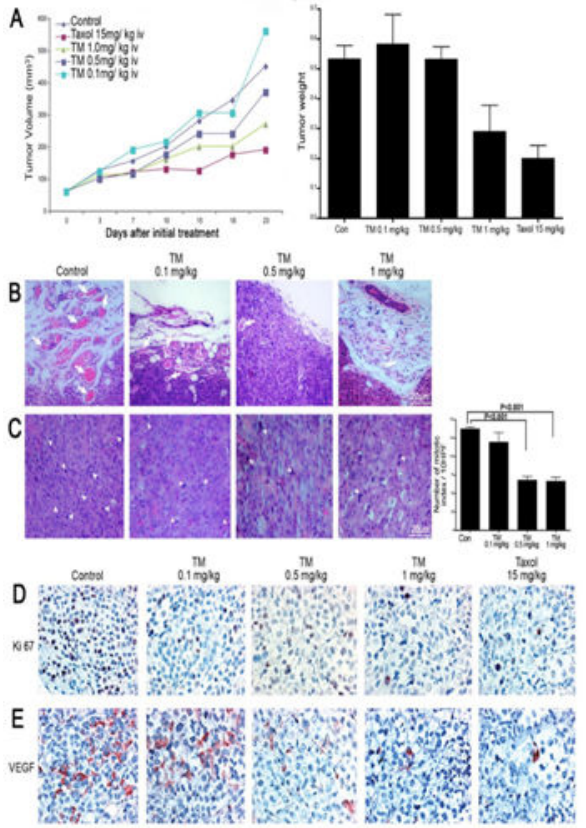

(a)

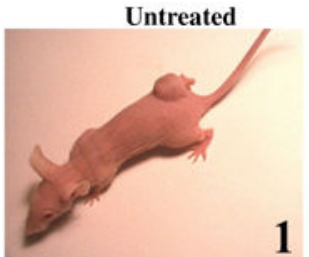

Tunicamycin Treated

1
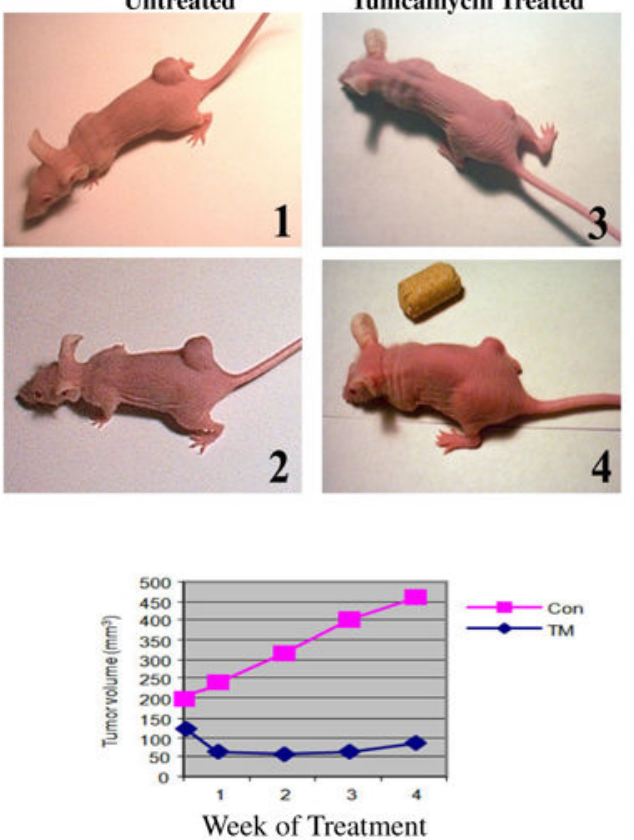

(b)

Figure 7.

Tunicamycin inhibits double (orthotopic tumor) and triple negative (xenograft) breast tumor progression. Staining of paraffin sections exhibits reduced microvessel density, reduced mitotic index as well as reduced Ki-67 and VEGF expression. 


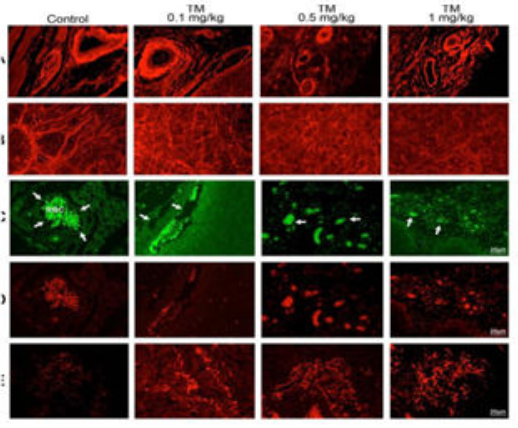

(a)

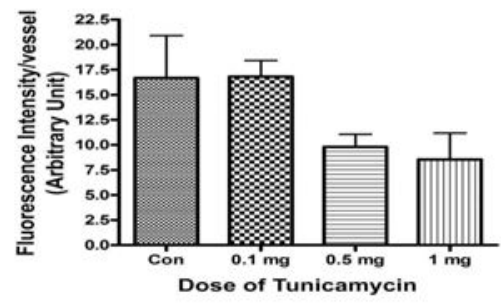

(b)
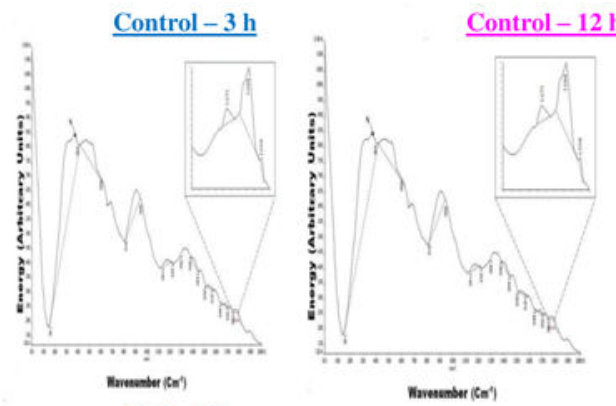

$\underline{T M-3 h}$

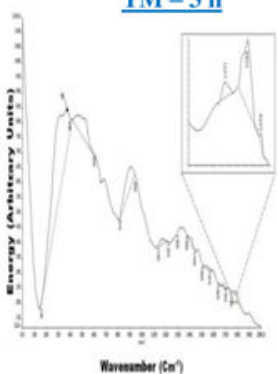

(c)

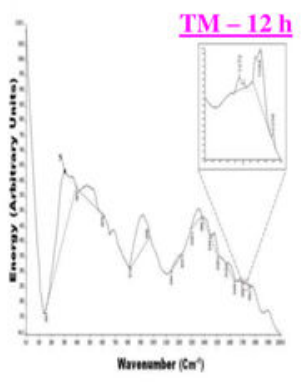

(d)

Figure 8.

Tunicamycin treatment develops "Er stress" in tumor microvasculature as well as in tumor cells (a \&b). Analysis of cellular proteome by Raman Spectroscopy supports protein denaturation following tunicamycin treatment (c \& d). 
(a)

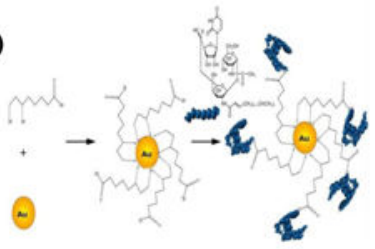

(b)

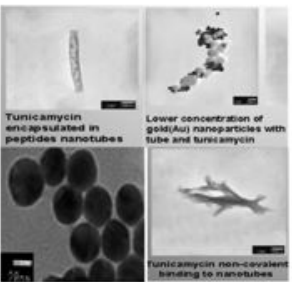

(c)

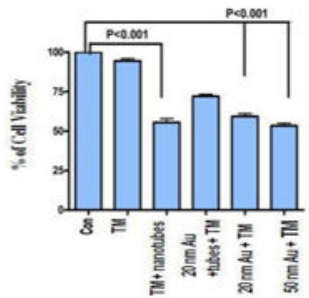

(d)
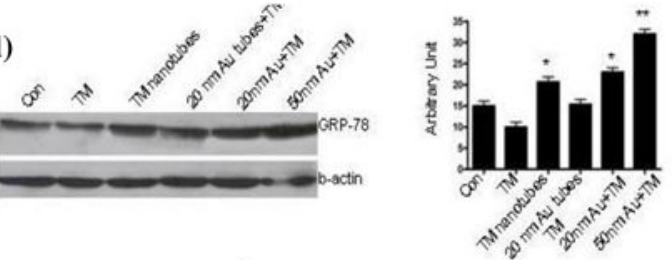

(e)
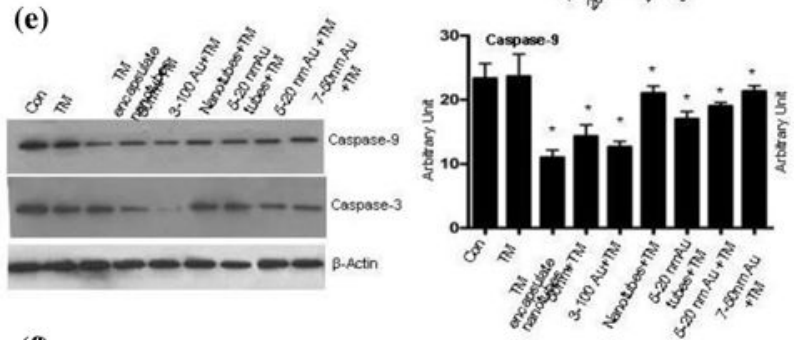

(f)

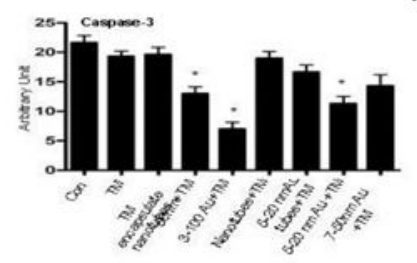

Figure 9.

Tunicamycin gold nanoparticles are three times more potent than the native compound. Tunicamycin nanoparticles reduces cellular proliferation by down regulating the expression of cyclin D1 and/or CDK4n (a, b, \& c). The cells experience "ER stress" (d) but does not undergo apoptosis. 

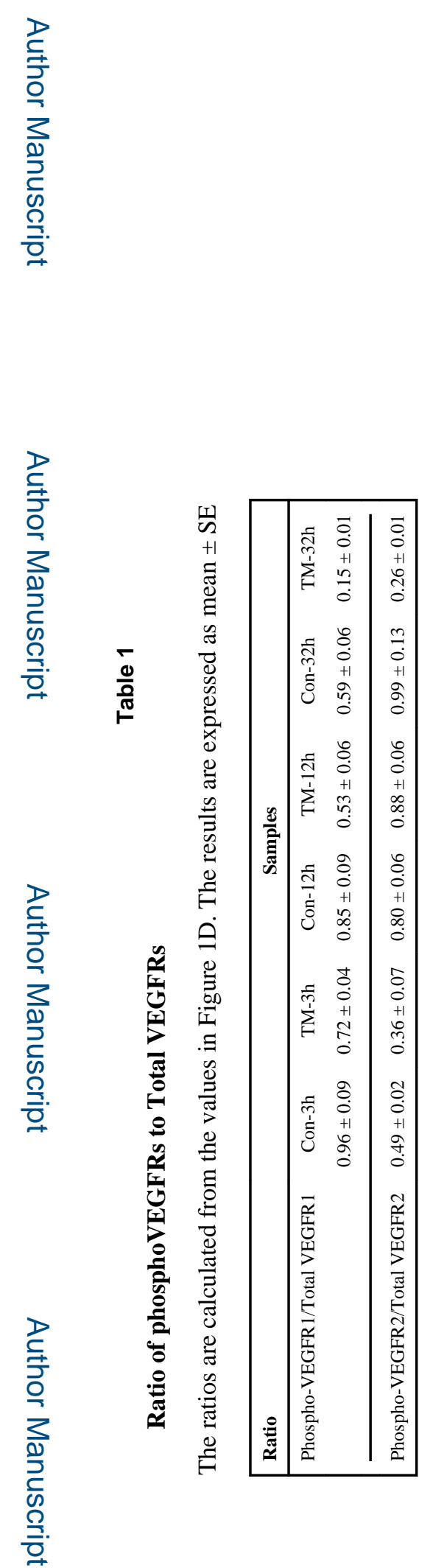

Adv Exp Med Biol. Author manuscript; available in PMC 2015 October 13. 
Table 2

Intensities of Raman Spectral bands in the $1700-1600 \mathrm{~cm}^{-1}$ region in capillary endothelial cells in the presence or absence of tunicamycin.

\begin{tabular}{|c|c|c|c|c|}
\hline Sample & Wave number $\left(\mathrm{cm}^{-1}\right)$ & Band Area* (absorbance) & S.D. & Change in band area $(\%)$ \\
\hline $3 \mathrm{~h}($ no TM) & 1694 & 0.5400 & 0.0787 & \\
\hline $3 \mathrm{~h}(1 \mu \mathrm{g} / \mathrm{ml} \mathrm{TM})$ & & 0.3600 & 0.0759 & $33.33 \downarrow$ \\
\hline $12 \mathrm{~h}($ no TM) & “ & 0.6880 & 0.1610 & \\
\hline $12 \mathrm{~h}(1 \mu \mathrm{g} / \mathrm{ml} \mathrm{TM})$ & & 0.4615 & 0.0710 & $32.92 \downarrow$ \\
\hline $3 \mathrm{~h}($ no TM $)$ & 1684 & 0.1500 & 0.0022 & \\
\hline $3 \mathrm{~h}(1 \mu \mathrm{g} / \mathrm{ml} \mathrm{TM})$ & & 0.1190 & 0.0022 & $20.63 \downarrow$ \\
\hline $12 \mathrm{~h}($ no $\mathrm{TM})$ & “ & 0.8104 & 0.1181 & \\
\hline $12 \mathrm{~h}(1 \mu \mathrm{g} / \mathrm{ml} \mathrm{TM})$ & & 0.4856 & 0.0477 & $40.08 \downarrow$ \\
\hline $3 \mathrm{~h}($ no TM $)$ & 1672 & 0.0408 & 0.0076 & \\
\hline $3 \mathrm{~h}(1 \mu \mathrm{g} / \mathrm{ml} \mathrm{TM})$ & & 0.0237 & 0.0047 & $41.85 \downarrow$ \\
\hline $12 \mathrm{~h}$ (no TM) & “ & 0.0607 & 0.0010 & \\
\hline $12 \mathrm{~h}(1 \mu \mathrm{g} / \mathrm{ml} \mathrm{TM})$ & & 0.0271 & 0.0084 & $55.39 \downarrow$ \\
\hline
\end{tabular}

S.D. $=$ standard deviation from the mean of three different samples analyzed in duplicate. Spectra were normalized using the Raman Spectroscopy band at $400-155 \mathrm{~cm}^{-1}$ which did not change. 